\title{
Nitrogen uptake and regeneration pathways in the equatorial Pacific: a basin scale modeling study
}

\author{
X. J. Wang ${ }^{1}$, R. Murtugudde ${ }^{1}$, and R. Le Borgne ${ }^{2}$ \\ ${ }^{1}$ Earth System Science Interdisciplinary Center University of Maryland, College Park, 20740, USA \\ ${ }^{2}$ Institut de Recherche pour le Développement Centre de Nouméa, B.P. A5, 98848 Nouméa Cédex, New Caledonia
}

Received: 2 July 2009 - Published in Biogeosciences Discuss.: 14 August 2009

Revised: 6 November 2009 - Accepted: 9 Novemver 2009 - Published: 24 November 2009

\begin{abstract}
It is well known that most primary production is fueled by regenerated nitrogen in the open ocean. Therefore, studying the nitrogen cycle by focusing on uptake and regeneration pathways would advance our understanding of nitrogen dynamics in the marine ecosystem. Here, we carry out a basin-scale modeling study, by assessing model simulations of nitrate and ammonium, and rates of nitrate uptake, ammonium uptake and regeneration in the equatorial Pacific. Model-data comparisons show that the model is able to reproduce many observed features of nitrate, ammonium, such as the deep ammonium maximum (DAM). The model also reproduces the observed de-coupling of ammonium uptake and regeneration, i.e., regeneration rate greater than uptake rate in the lower euphotic zone. The de-coupling largely explains the observed DAM in the equatorial Pacific Ocean. Our study indicates that zooplankton excretion and remineralization of organic nitrogen play a different role in nitrogen regeneration. Rates of zooplankton excretion vary from $<0.01 \mathrm{mmol} \mathrm{m}^{-3} \mathrm{~d}^{-1}$ to $0.1 \mathrm{mmol} \mathrm{m}^{-3} \mathrm{~d}^{-1}$ in the upper euphotic zone while rates of remineralization fall within a narrow range $\left(0.015-0.025 \mathrm{mmol} \mathrm{m}^{-3} \mathrm{~d}^{-1}\right)$. Zooplankton excretion contributes up to $70 \%$ of total ammonium regeneration in the euphotic zone, and is largely responsible for the spatial variability of nitrogen regeneration. However, remineralization provides a steady supply of ammonium in the upper ocean, and is a major source of inorganic nitrogen for the oligotrophic regions. Overall, ammonium generation and removal are approximately balanced over the top $150 \mathrm{~m}$ in the equatorial Pacific.
\end{abstract}

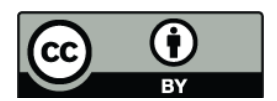

Correspondence to: X. Wang (wwang@essic.umd.edu)

\section{Introduction}

New production, which is achieved from nitrogen inputs to an ecosystem and often taken as nitrate consumption, is used as a proxy for export production in steady-state ecosystems. As such, it characterizes the "biological pump" efficiency. Hence, new production has been widely studied in the equatorial Pacific, using both observation (Dugdale et al., 1992; McCarthy et al., 1996; Turk et al., 2001; Raimbault et al., 1999; Aufdenkampe et al., 2001; Aufdenkampe et al., 2002) and modeling approaches (Laws, 2004; Chavez and Barber, 1987; Radenac et al., 2001; Wang et al., 2006b; Aufdenkampe and Murray, 2002; Stoens et al., 1998, 1999; Jiang et al., 2003).

While nitrate is the dominant form of inorganic nitrogen in the marine system, most primary production is fueled by regenerated nitrogen, primarily ammonium. For instance, ammonium supply could sustain up to $85 \%$ of the total inorganic nitrogen utilization by phytoplankton in the equatorial Pacific (Raimbault et al., 1999). However, our knowledge is limited in terms of understanding the ammonium dynamics and associated processes such as nitrogen regeneration and regenerated production. To date, there are only a few studies addressing ammonium uptake and regeneration in the equatorial Pacific (e.g., Raimbault et al., 1999; Wang et al., 2005; Le Bouteiller et al., 2003; McCarthy et al., 1996), which clearly hampers our ability to understand the marine nitrogen cycle.

There have been several studies measuring ammonium concentrations in the equatorial Pacific, which show extremely low concentrations near the surface, but deep ammonium maxima (DAM) at the bottom of the euphotic zone (Eldin and Rodier, 2003; Aufdenkampe et al., 2002; Raimbault et al., 1999; Matsumoto et al., 2004; Murray et al., 1995). The observed DAM often exhibits a patchy distribution in the equatorial Pacific. In addition, the DAM depth

Published by Copernicus Publications on behalf of the European Geosciences Union. 
does not vary much, approximately located at $100 \mathrm{~m}$. These observed features in ammonium dynamics, together with the relatively low concentrations of ammonium, may provide a sensitive and realistic check on the performance of biogeochemical/ecosystem models. However, there has been little report of ammonium dynamics in ecosystem and biogeochemical modeling studies.

Ammonium, as a product of nitrogen regeneration, is produced primarily from zooplankton excretion and remineralization of dissolved organic nitrogen (DON). Distribution and behavior of ammonium are also influenced by biological uptake. Early field studies have shown de-coupling of ammonium uptake and ammonium regeneration: uptake rate greater than regeneration rate in the upper euphotic zone, but regeneration rate greater than uptake rate in the lower euphotic zone (Raimbault et al., 1999). One would therefore ask if the observed DAM is ascribed to the subsurface surplus of ammonium regeneration. While field data provide crucial information such as spatial variability, field measurements remain difficult and may introduce potential errors and uncertainties because simultaneous processes may interact with rate measurements (Wankel et al., 2007).

Our previous studies have been to understand the spatial and temporal variations in biogeochemical parameters in the equatorial Pacific, including new production (Wang et al., 2006b), sea surface partial pressure $\mathrm{CO}_{2}\left(p \mathrm{CO}_{2}\right)$ and seaair $\mathrm{CO}_{2}$ fluxes (Wang et al., 2006a). Our recent work has been to better understand the nitrogen cycle, including the distributions and behaviors of dissolved and particulate organic nitrogen (Wang et al., 2008). There are still many issues dealing with the nitrogen cycle in the marine ecosystem, which are not fully understood. In this study, we focus on nitrogen uptake and regeneration pathways. The objective of this study is to resolve some of the processes related to nitrogen uptake and regeneration, which have not received much attention. Our approach includes (1) the use of field data collected from the equatorial Pacific for parameterization of nitrogen regeneration in our basin scale physicalbiogeochemical model, and (2) integrated model validations, not only for distributions of nitrate and ammonium, but also for rates of nitrate uptake, ammonium uptake and regeneration.

\section{Model description}

\subsection{Ocean physical-biogeochemical model}

The ocean general circulation model (OGCM) is a reducedgravity, primitive-equation, sigma-coordinate model that is coupled to an advective atmospheric mixed layer model (Gent and Cane, 1989; Murtugudde et al., 1996. The model has 20 vertical layers with variable thicknesses. The uppermost layer, the mixed layer, is determined by surface turbulent kinetic energy generation, dynamic instability mixing, and convective mixing to remove static instabilities (Chen et al., 1994). The thickness of the last layer is a prognostic variable while the remaining sigma layers are a specified constant fraction of total thickness of the model domain below the mixed layer. The mixed layer ranges from 10 to $50 \mathrm{~m}$ along the equator, and the remaining layers in the euphotic zone $(0-120 \mathrm{~m})$ are approximately $10 \mathrm{~m}$ in thickness. The model is set up for the Pacific domain between $30^{\circ} \mathrm{S}-30^{\circ} \mathrm{N}$ with zonal resolution of $1^{\circ}$, and variable meridional resolutions of $0.3-0.6^{\circ}$ between $15^{\circ} \mathrm{S}-15^{\circ} \mathrm{N}\left(1 / 3^{\circ}\right.$ at latitudes $<10^{\circ}$ ), increasing to $2^{\circ}$ at the northern and southern boundaries. In the "sponge layer" ( $10^{\circ}$ band) near the boundaries, temperature, salinity, and nitrate are gradually relaxed back towards climatology.

The model is forced by monthly means of solar radiation, cloudiness, precipitation and 6-day means of surface wind stress from the NCEP/NCAR reanalysis (Kalnay et al., 1996). There are two types of model simulation, i.e., climatological run and interannual run. For the climatological run, the model is forced and spun up for 30 years by climatological, seasonal forcing with initial conditions from the WOA98 atlas. For the interannual run, the model is forced by interannual monthly precipitation and 6-day wind stress with initial conditions taken from the climatological run. In this study, we perform an interannual run starting from 1980, and use model outputs during the period of 1992-1996 for model sensitivity studies and validations because of most field data were collected during this period.

The biogeochemical model consists of three nutrients (nitrate, ammonium, dissolved iron) and seven biological pools. The biological components include large (L) and small (S) cells of phytoplankton $\left(\mathrm{P}_{\mathrm{S}}\right.$ and $\left.\mathrm{P}_{\mathrm{L}}\right)$, zooplankton $\left(\mathrm{Z}_{\mathrm{S}}\right.$ and $Z_{L}$ ) and detritus $\left(D_{S}\right.$ and $\left.D_{L}\right)$, and DON. Small phytoplankton represents the picophytoplankton, large phytoplankton the diatoms and other autotrophic plankton, small and large zooplankton the micro- and meso-zooplankton, respectively. (Le Borgne and Landry, 2003). All biogeochemical fields are computed in a similar manner to physical fields for all 20 layers without restoration. All biological components are carried in terms of their nitrogen equivalence, except for dissolved iron which is modeled explicitly, using a single Fe:N ratio for all biological compartments except the large phytoplankton. Model structure, equations and biological parameters were given by Wang et al. (2008). This model does not simulate nitrogen fixation, which may result in underestimation of nitrogen uptake. However, a recent study shows that nitrogen fixation rate is very low in the upwelling region where nitrate concentration is often high (Bonnet et al., 2009). 


\subsection{Computation of nitrogen uptake and regeneration}

Here, we describe the parameterization of nitrogen uptake and regeneration, and the relevant processes. For a given layer, rates $\left(\mathrm{mmol} \mathrm{N} \mathrm{m}^{-3} \mathrm{~d}^{-1}\right)$ of nitrate uptake (NP) and ammonium uptake (AP) are computed as:

$\mathrm{NP}=\mu_{\mathrm{S}} \mathrm{P}_{\mathrm{S}} \frac{\mathrm{N}_{\mathrm{S}_{-} \mathrm{UP}}}{\mathrm{N}_{\mathrm{S} \_\mathrm{UP}}+\mathrm{A}_{\mathrm{UP}}}+\mu_{\mathrm{L}} \mathrm{P}_{\mathrm{L}} \frac{\mathrm{N}_{\mathrm{L}_{-} \mathrm{UP}}}{\mathrm{N}_{\mathrm{L}_{-} \mathrm{UP}}+\mathrm{A}_{\mathrm{UP}}}$,

$\mathrm{AP}=\mu_{\mathrm{S}} \mathrm{P}_{\mathrm{S}} \frac{\mathrm{A}_{\mathrm{UP}}}{\mathrm{N}_{\mathrm{S}_{-} \mathrm{UP}}+\mathrm{A}_{\mathrm{UP}}}+\mu_{\mathrm{L}} \mathrm{P}_{\mathrm{L}} \frac{\mathrm{A}_{\mathrm{UP}}}{\mathrm{N}_{\mathrm{L}_{-} \mathrm{UP}}+\mathrm{A}_{\mathrm{UP}}}$,

where $\mu_{\mathrm{S}}$ and $\mu_{\mathrm{L}}$ are the growth rate for small and large phytoplankton, respectively, which are computed as a function of temperature $(T)$, light $(E)$, and nutrients ( $\mathrm{N}$ and $\mathrm{Fe})$. The terms $\mathrm{N}_{S_{-} U P}$ and $\mathrm{N}_{\mathrm{L}_{-} U P}$ are the fractions of phytoplankton production due to nitrate $\left(\mathrm{NO}_{3}\right)$ uptake by small and large phytoplankton, respectively, and $\mathrm{A}_{\mathrm{UP}}$ the fraction of phytoplankton production due to ammonium $\left(\mathrm{NH}_{4}\right)$ uptake. These fractions are determined as:

$\mathrm{N}_{\mathrm{S}_{-} \mathrm{UP}}=\frac{\mathrm{NO}_{3}}{\mathrm{~K}_{\mathrm{S}_{-} \mathrm{NO}_{3}}+\mathrm{NO}_{3}}\left(1-\frac{\mathrm{NH}_{4}}{\mathrm{~K}_{\mathrm{NH}_{4}}+\mathrm{NH}_{4}}\right)$,

$\mathrm{N}_{\mathrm{L}_{-} \mathrm{UP}}=\frac{\mathrm{NO}_{3}}{\mathrm{~K}_{\mathrm{L}_{-} \mathrm{NO}_{3}}+\mathrm{NO}_{3}}\left(1-\frac{\mathrm{NH}_{4}}{\mathrm{~K}_{\mathrm{NH}_{4}}+\mathrm{NH}_{4}}\right)$,

$\mathrm{A}_{\mathrm{UP}}=\frac{\mathrm{NH}_{4}}{\mathrm{~K}_{\mathrm{NH}_{4}}+\mathrm{NH}_{4}}$

where $\mathrm{K}_{\mathrm{S}_{-} \mathrm{NO}_{3}}$ and $\mathrm{K}_{\mathrm{L} \_\mathrm{NO}_{3}}$ are half saturation constants for nitrate uptake by small and large phytoplankton, and $\mathrm{K}_{\mathrm{NH}_{4}}$ half saturation constant for ammonium uptake.

Nitrogen regeneration includes zooplankton excretion (ZE), and remineralization (DR) from DON and detritus:

$\mathrm{ZE}=\left(\mathrm{r}_{\mathrm{S}} \mathrm{Z}_{\mathrm{S}}+\mathrm{r}_{\mathrm{L}} \mathrm{Z}_{\mathrm{L}}\right)(1-\chi)$,

$\mathrm{DR}=\mathrm{c}_{\mathrm{DON}} \mathrm{DON}+\mathrm{c}_{\mathrm{DS}} \mathrm{D}_{\mathrm{S}}+\left(\mathrm{c}_{\mathrm{DL}} \mathrm{D}_{\mathrm{L}}\right)(1-\zeta)$,

where $r_{S}$ and $r_{L}$ are the excretion constants for small and large zooplankton, respectively, $\chi$ the mean percentage of excreted nitrogen as DON, c the rate of remineralization or decomposition, and $\zeta$ the percentage of decomposed large detritus going to the DON pool.

In the model, biological uptake removes both nitrate and ammonium, nitrogen regeneration only produces ammonium. Thus, net nitrate production (NNP) and net ammonium production (NAP) are computed as:

$\mathrm{NNP}=\phi \mathrm{NH}_{4}-\mathrm{NP}$,

$\mathrm{NAP}=\mathrm{ZE}+\mathrm{DR}-\mathrm{AP}-\varphi \mathrm{NH}_{4}$

where $\varphi$ is the specific nitrification rate.

\section{Model parameterization and sensitivity studies}

\subsection{Parameterization of nitrogen regeneration}

While there is limited information about the rates of mesozooplankton excretion and DON remineralization in this region, there is evidence of significant difference between these two processes. According to Le Borgne and Rodier (1997), measured total excretion rate for large zooplankton $(>200 \mu \mathrm{m})$ ranges from $\sim 0.5$ to $\sim 2 \mathrm{~d}^{-1}$ in the central equatorial Pacific. Field measurements reveal a large range of ammonium regeneration $(<20$ to $\sim 200 \mathrm{nmol} \mathrm{m}^{-3} \mathrm{~d}^{-1}$ ) in the euphotic zone of the central equatorial Pacific (Raimbault et al., 1999). Ammonium regeneration shows no relationship with DON, suggesting that the majority of ammonium is generated from zooplankton excretion in the euphotic zone. On the other hand, we assume that below the photic zone (ca. $100 \mathrm{~m}$ ), the majority of the regenerated ammonium results from DON remineralization. This assumption yields a maximum remineralization rate of $\sim 0.003 \mathrm{~d}^{-1}$, which is similar to that (e.g., a turnover rate of 0.9 year) for the northeastern Pacific (e.g., Bronk, 2002).

Turnover time for DON has a large range in the open ocean (Bronk, 2002), which is a function of the DON pool composition. In general, surface DON, consisting of a considerable amount of labile and semi-labile components, has a short turnover time whereas deep water DON, dominated by refractory component, has a relatively long turnover time (Dadou et al., 2001; Hopkinson et al., 2002; Roussenov et al., 2006). Davis and Benner (2005) have reported that degradation of different organic material follows the following sequence: particulate organic matter (POM), fresh dissolved organic matter (DOM), old DOM. Since our model has a single DON pool, it is necessary to apply a variable, depthdependent remineralization rate to represent a vertical distribution of different classes of DON.

To set the rates for zooplankton excretion, DON remineralization and detritus decomposition, we carried out a series of test runs using a range of values. Then we compared the model simulation of nitrate, ammonium, DON and PON concentrations, and ammonium regeneration rates with observations. Integrated comparisons showed that the best agreement occurred when we set the zooplankton excretion rates, $r$, to $0.53 \mathrm{~d}^{-1}$ and $0.44 \mathrm{~d}^{-1}$ for small and large zooplankton, respectively. The excretion rates are near the low end of the derived range from limited observations in the equatorial Pacific (Le Borgne and Rodier, 1997). For DON remineralization rate, we use a variable $c_{\text {DONo }}: 0.0025 \mathrm{~d}^{-1}$ and $0.0008 \mathrm{~d}^{-1}$ for the upper $100 \mathrm{~m}$ water column and below $300 \mathrm{~m}$, respectively. We apply a linear decrease to the remineralization rate in the water column between $100 \mathrm{~m}$ and $300 \mathrm{~m}$ depth. Such approach has enabled the model to reproduce many observed biogeochemical features in the equatorial Pacific, e.g., the spatial and temporal variations in DON and PON (Wang et al., 2008). 

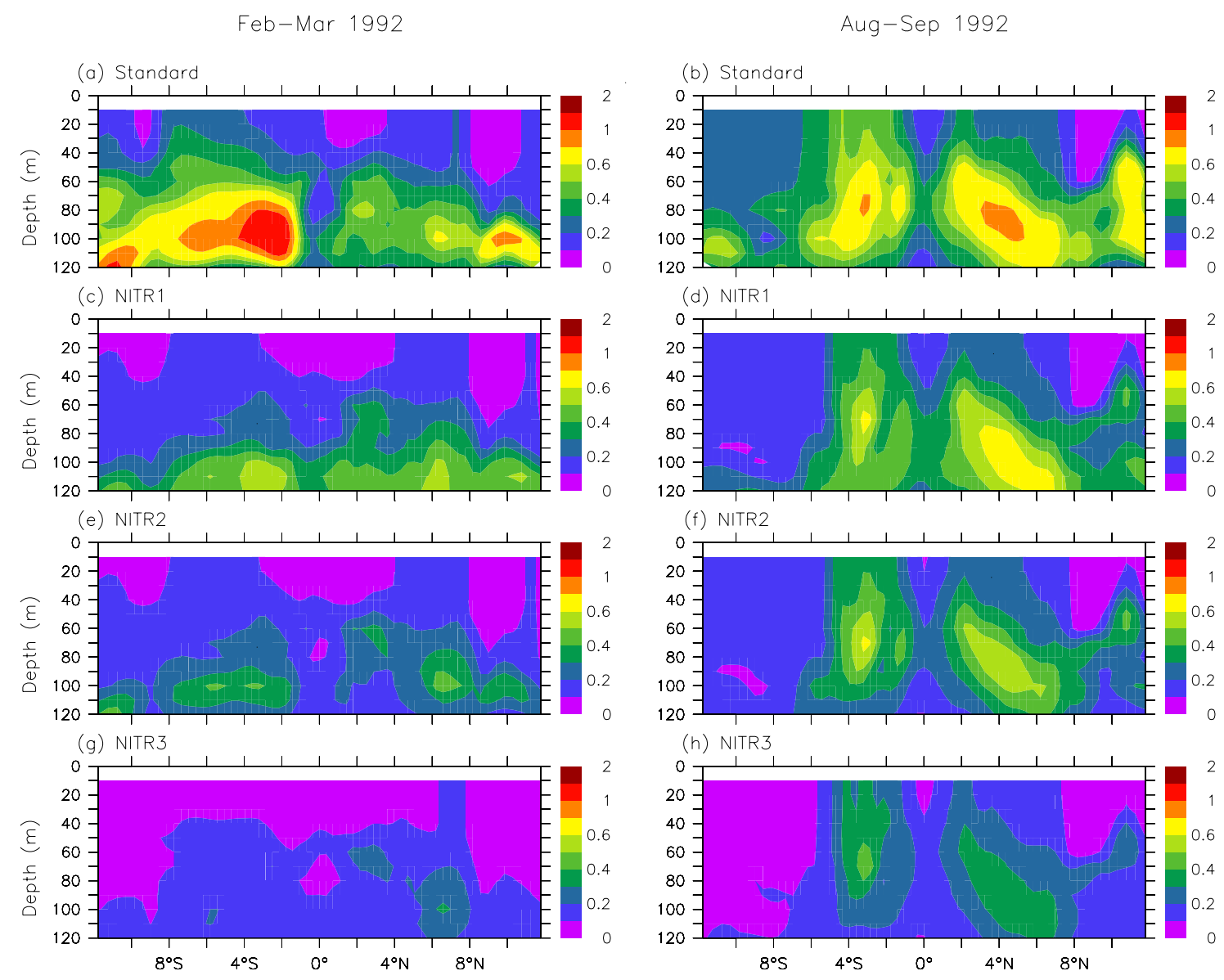

Fig. 1. Modeled ammonium distributions from a) and (b) the standard, (c) and (d) NITR1, (e) and (f) NITR2, and (g) and (h) NITR3 simulations along $140^{\circ} \mathrm{W}$ during February-March, 1992 (left column) and August-September, 1992 (right column).

\subsection{Sensitivity to nitrification}

Traditionally, photoinhibition has been applied to nitrification in biogeochemical models in various ways (e.g., Denman, 2003; Moore et al., 2002; Wang et al., 2006b; Christian et al., 2002; Jiang et al., 2003; Aumont and Bopp, 2006). However, recent evidence suggests that nitrification rates in the euphotic zone are larger than previously thought (Yool et al., 2007). Here, we carried out a sensitivity study consisting of four simulations: standard, NITR1, NITR2 and NITR3. For the standard simulation, nitrification $\left(0.04 \mathrm{~d}^{-1}\right)$ occurs only below the euphotic zone (Wang et al., 2008). For the NITR1 experiment, nitrification rate is constant $\left(0.02 \mathrm{~d}^{-1}\right)$ throughout the water column. The NITR2 experiment has a low rate $\left(0.02 \mathrm{~d}^{-1}\right)$ for the euphotic zone, and high rate $\left(0.06 \mathrm{~d}^{-1}\right)$ below the euphotic zone. The NITR3 has a constant specific nitrification rate of $0.06 \mathrm{~d}^{-1}$ throughout the water column. Our choice for the range $\left(0.02-0.06 \mathrm{~d}^{-1}\right)$ of nitrification rate is close to those used in most biogeochemical models (e.g., Jiang et al., 2003; Moore et al., 2002; Aumont and Bopp, 2006).
Biogeochemical data were collected along $140^{\circ} \mathrm{W}$ in 1992 during a warm event (February-March) and a cold event (August-September) (Murray et al., 1995). Ammonium concentration was less than $0.1 \mathrm{mmol} \mathrm{m}^{-3}$ in the surface waters during both events. The observation showed marked differences in the subsurface ammonium between the two periods (See Figs. 3 and 4 in Murray et al., 1995). During the warm event, there was little DAM north of the equator, but strong DAM (ammonium concentration $>1 \mathrm{mmol} \mathrm{m}^{-3}$ ) south of the equator. However, the sub-surface ammonium concentrations were similar $\left(<0.5 \mathrm{mmol} \mathrm{m}^{-3}\right)$ both sides of the equator during the cold period. Figure 1 presents modeled ammonium distributions along $140^{\circ} \mathrm{W}$ for the same two periods from the sensitivity study. The NITR2 and NITR3 simulations under-estimate ammonium concentration whereas the standard and NITR1 simulations reproduce some of the observed features in ammonium distribution.

Field measurements of nitrate and ammonium were carried out along $150^{\circ} \mathrm{W}$ during November 1994 in the equatorial Pacific (Raimbault et al., 1999). Modeled concentrations of nitrate and ammonium for the same time and location are 

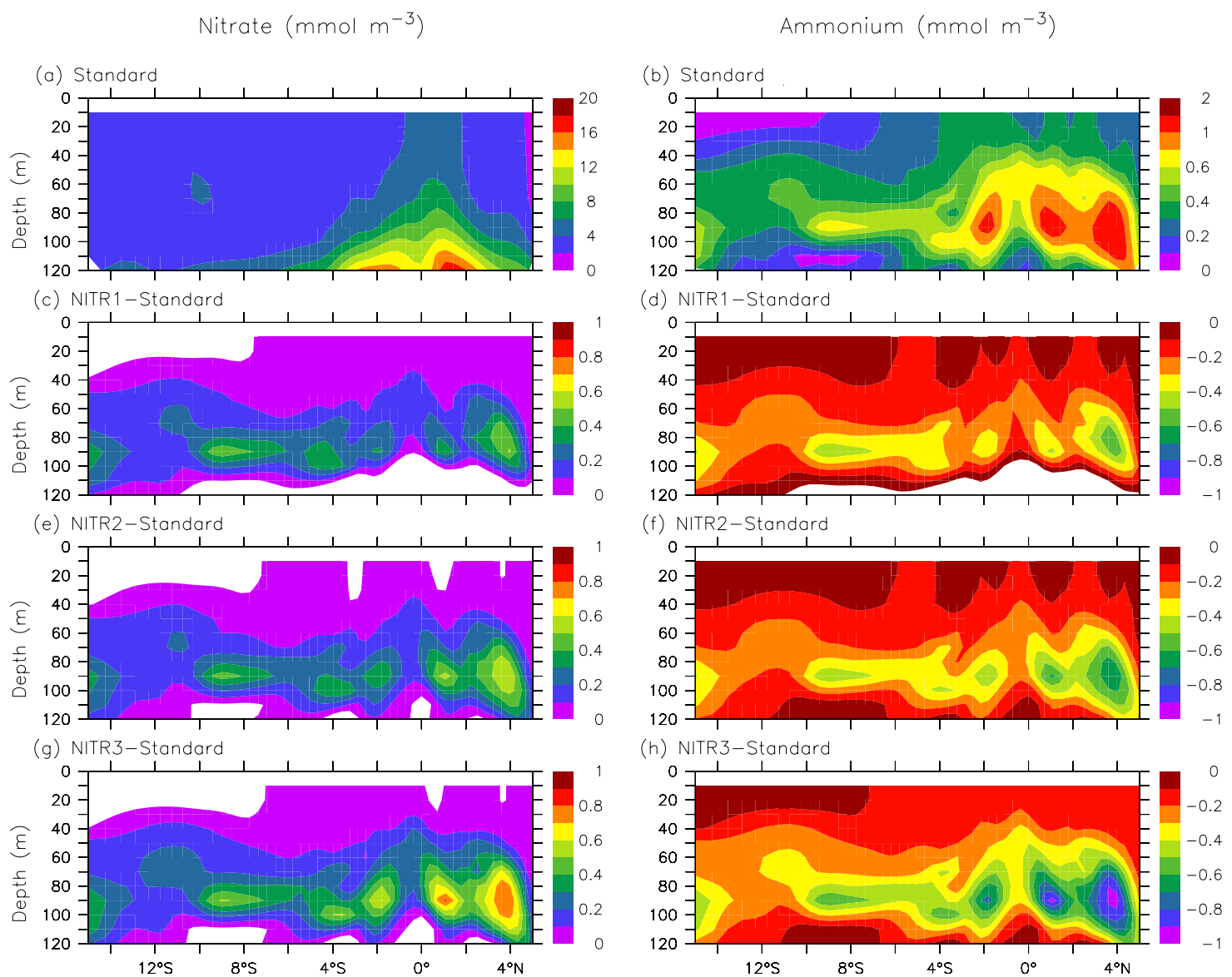

Fig. 2. Modeled distributions of (a) nitrate and (b) ammonium from the standard simulation, and differences in nitrate (left column) and ammonium (right column) between the standard simulation and (c) and (d) NITR1, (e) and (f) NITR2, and (g) and (h) NITR3 along $150^{\circ}$ W during November, 1994.

presented in Fig. 2. Overall, increasing specific nitrification rate leads to increased concentrations of nitrate but decreased concentrations of ammonium at $\sim 100 \mathrm{~m}$ depth. This modeling study indicates that meridional distributions of surface nitrate are not sensitive to the parameterization of nitrification commonly used in the biogeochemical models, which was also noted by Mongin et al. (2003). Our model-data comparisons demonstrate that the model can reproduce observed features (e.g., spatial pattern and vertical distributions) in the nitrate distribution, with or without photoinhibition of nitrification. The standard simulation with zero-nitrification overestimates ammonium concentrations in the euphotic zone (Fig. 2b) whereas the NITR3 simulation with the highest specific nitrification rate $\left(0.06 \mathrm{~d}^{-1}\right)$ under-estimates ammonium concentration (http://www.biogeosciences.net/6/2647/2009/ bg-6-2647-2009-supplement.pdf, Fig. 1a). It appears that simulated ammonium concentrations $\left(0.1-0.8 \mathrm{mmol} \mathrm{m}^{-3}\right)$ in the NITR1 (i.e., a constant specific nitrification rate of $0.02 \mathrm{~d}^{-1}$ ) simulation (http://www.biogeosciences.net/6/ 2647/2009/bg-6-2647-2009-supplement.pdf, Fig. 2a) are the closest to those from observation (see Fig. 4 in Raimbault et al., 1999).

Nitrogen uptake and regeneration were also measured along $150^{\circ} \mathrm{W}$ during November 1994 in the equatorial $\mathrm{Pa}$ cific (Raimbault et al., 1999), which allows us to further assess modeled ammonium dynamics. Figure 3 shows model simulations of nitrate and ammonium uptake for the same period from the sensitivity study. In general, increasing specific nitrification rate results in an increase in nitrate uptake and a decrease in ammonium uptake. However, the changes in nitrate and ammonium uptake occur mainly in the surface waters within the $5^{\circ} \mathrm{N}-5^{\circ} \mathrm{S}$ band whereas the changes in nitrate and ammonium concentrations are found in the sub-surface between $5^{\circ} \mathrm{N}$ and $15^{\circ} \mathrm{S}$. Interestingly, total nitrogen uptake (i.e., the sum of nitrate uptake and ammonium uptake) remains the same along 

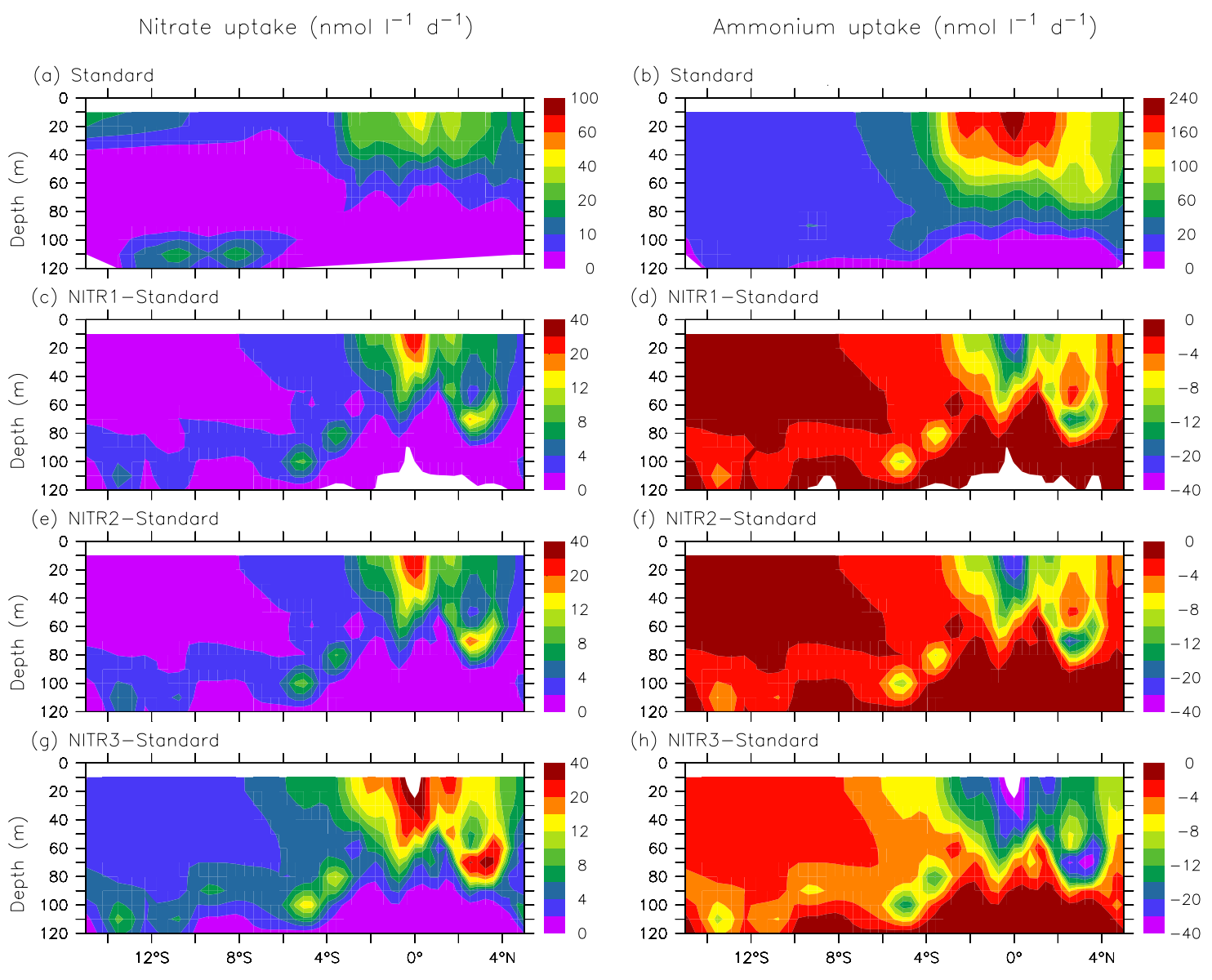

Fig. 3. Modeled rates of (a) nitrate uptake and (b) ammonium uptake from the standard simulation, and differences in nitrate uptake (left column) and ammonium uptake (right column) between the standard simulation and (c) and (d) NITR1, (e) and (f) NITR2, and (g) and (h) NITR3 along $150^{\circ} \mathrm{W}$ during November, 1994.

$150^{\circ} \mathrm{W}$ no matter which specific nitrification rate is applied (Table 1, http://www.biogeosciences.net/6/2647/2009/ bg-6-2647-2009-supplement.pdf, Figs. 1f and 2f). Moreover, modeled ammonium regeneration is not sensitive to the parameterization of nitrification in the central equatorial Pacific (http://www.biogeosciences.net/6/2647/2009/ bg-6-2647-2009-supplement.pdf, Figs. 1d and 2d).

Table 1 illustrates the comparisons of observed and modeled rates of nitrate and ammonium uptake along $150^{\circ} \mathrm{W}$ during November 1994. The integrated rates of nitrate and ammonium uptake from the observations range from 0.5 and $4.4 \mathrm{mmol} \mathrm{m}^{-2} \mathrm{~d}^{-1}$ to 2.7 and $12.5 \mathrm{mmol} \mathrm{m}^{-2} \mathrm{~d}^{-1}$, respectively. While the standard simulation produces similar rates of nitrate uptake (i.e., $0.3-2.7 \mathrm{mmol} \mathrm{m}^{-2} \mathrm{~d}^{-1}$ ) to those in the observations, and slightly lower rates of ammonium uptake (i.e., $1.3-12.1 \mathrm{mmol} \mathrm{m}^{-2} \mathrm{~d}^{-1}$ ) relative to the observations, the model under-estimates both rates of nitrate and ammonium uptake between $2.5^{\circ} \mathrm{S}$ and $10^{\circ} \mathrm{S}$. Increasing specific nitrification rate appears to improve nitrate uptake for this area, but leads to further under-estimations of ammonium uptake.

\section{Model results and discussion}

There are two distinct regions in the equatorial Pacific: the upwelling region in the central and eastern Pacific and the warm pool to the west (Picaut et al., 2001; Le Borgne et al., 2002). The thermocline is much shallower, with high surface nutrient concentrations in the upwelling region. In contrast, the warm pool has a deeper thermocline and nutricline, with undetectable nutrient concentrations in the mixed layer. As a result, the central and eastern equatorial Pacific often has mesotrophic conditions whereas the west warm pool experiences oligotrophic conditions.

Apart from the distinct zonal variability, the equatorial Pacific also reveals meridional asymmetry in many biogeochemical fields, including nitrate, silicate, and carbon fields in the equatorial Pacific (Feely et al., 1997; Jiang and Chai, 2005; Murray et al., 1995; Archer et al., 1997; Dugdale et al., 2002; Wang et al., 2006a), which may be largely associated with the asymmetries in mass exchanges between the equatorial and off-equatorial Pacific Ocean (Kug et al., 2003). In 
Table 1. Comparisons of modeled and measured rates of nitrate uptake and ammonium uptake $\left(\mathrm{mmol} \mathrm{N} \mathrm{m}^{-2} \mathrm{~d}^{-1}\right)$ integrated over $0-120 \mathrm{~m}$ along $150^{\circ} \mathrm{W}$ during November 1994 .

\begin{tabular}{|c|c|c|c|c|}
\hline \multirow{2}{*}{$\begin{array}{l}\text { Data*/ } \\
\text { experiment }\end{array}$} & \multicolumn{2}{|c|}{ Upwelling area } & \multirow{2}{*}{$\begin{array}{c}\text { Mesotrophic } \\
7^{\circ} \mathrm{S}-10^{\circ} \mathrm{S}\end{array}$} & \multirow{2}{*}{$\begin{array}{l}\text { Oligotrophic } \\
11.5^{\circ} \mathrm{S}-13^{\circ} \mathrm{S}\end{array}$} \\
\hline & $1^{\circ} \mathrm{N}-1^{\circ} \mathrm{S}$ & $2.5^{\circ} \mathrm{S}-5.5^{\circ} \mathrm{S}$ & & \\
\hline \multicolumn{5}{|c|}{ Nitrate uptake } \\
\hline Data & $1.65-1.87$ & $1.77-2.68$ & $0.9-1.62$ & $0.47-0.49$ \\
\hline Standard & $1.06-2.67$ & $0.68-1.13$ & $0.29-0.66$ & $0.46-0.52$ \\
\hline NITR1 & $1.53-3.11$ & $0.57-2.09$ & $0.69-0.96$ & $0.89-0.99$ \\
\hline NITR2 & $1.56-3.26$ & $0.58-2.10$ & $0.69-0.96$ & $0.92-1.01$ \\
\hline NITR3 & $1.92-4.10$ & $0.78-2.48$ & $0.9-1.15$ & $1.05-1.14$ \\
\hline \multicolumn{5}{|c|}{ Ammonium uptake } \\
\hline Data & $7.05-12.54$ & $8.07-10.72$ & $6.94-8.21$ & $4.38-5.5$ \\
\hline Standard & $8.02-12.06$ & $5.96-9.56$ & $1.55-2.63$ & $1.33-1.50$ \\
\hline NITR1 & $8.93-11.09$ & $2.25-9.38$ & $1.56-1.86$ & $1.38-1.46$ \\
\hline NITR2 & $8.90-10.97$ & $2.25-9.37$ & $1.55-1.86$ & $1.37-1.43$ \\
\hline NITR3 & $8.00-9.47$ & $1.92-8.43$ & $1.31-1.56$ & $1.14-1.20$ \\
\hline \multicolumn{5}{|c|}{ Total N uptake } \\
\hline Standard & 11.79 & 5.36 & 2.43 & 2.26 \\
\hline NITR3 & 11.76 & 5.35 & 2.43 & 2.26 \\
\hline
\end{tabular}

* Data are from Raimbault et al. (1999)

general, surface nutrient concentrations and rates of biological production and remineralization are higher to the south of the equator than to the north in the upwelling region (Le Borgne and Landry, 2003). In this section, we present modeled nitrogen uptake and regeneration for the period of 19921996 from the NITR1 simulation, and discuss the spatial variability in relevant processes.

\subsection{Nitrogen uptake and regeneration}

Modeled rates of nitrate uptake, ammonium uptake and regeneration for 1992-1996 are presented in Fig. 4. The rate of nitrate uptake ranges from 10 to $60 \mathrm{nmol} \mathrm{l}^{-1} \mathrm{~d}^{-1}$ in the upper euphotic zone of the central and eastern equatorial Pacific, which is similar to those measured along $150^{\circ} \mathrm{W}$ during November 1994 (Raimbault et al., 1999). The integrated rate of nitrate uptake from model simulation ranges from $\sim 0.5$ to $>5 \mathrm{mmol} \mathrm{m}^{-2} \mathrm{~d}^{-1}$, with the highest rates in the eastern equatorial Pacific within a few degrees on the equator (Fig. 4b). This feature has been observed along $180^{\circ}$, i.e., much higher rate of nitrate uptake at $0^{\circ}$ than at $3^{\circ} \mathrm{S}$ (Le Bouteiller et al., 2003). Ammonium uptake displays significantly higher rates but smaller spatial variability than nitrate uptake. For instance, integrated rate of ammonium uptake ranges from $\sim 2$ to $\sim 9 \mathrm{mmol} \mathrm{m}^{-2} \mathrm{~d}^{-1}$, which is $2-4$ times of those of nitrate uptake. Previous observations along $140^{\circ} \mathrm{W}$ show similar magnitudes and meridional distributions in the integrated rates of nitrate uptake $\left(0.5-5 \mathrm{mmol} \mathrm{m}^{-2} \mathrm{~d}^{-1}\right)$ and ammonium uptake (3-20 mmol m $\mathrm{m}^{-2} \mathrm{~d}^{-1}$ ) (McCarthy et al., 1996).
The model simulation shows similarity between ammonium uptake and ammonium regeneration, especially in the central equatorial Pacific, which is consistent with observations (Raimbault et al., 1999). Interestingly, both model simulations and the observations demonstrate that rate of ammonium regeneration is generally lower than that of ammonium uptake in the upper euphotic zone, but higher in the lower euphotic zone in the central equatorial Pacific. The model also produces the highest rate of integrated ammonium uptake along the equator (Fig. $4 \mathrm{~d}$ ), but the highest rate of integrated ammonium regeneration off the equator (Fig. 4f).

There are pronounced differences in the meridionalvertical distributions of nitrate uptake, ammonium uptake and regeneration among the western warm pool (WWP), central (CEP) and eastern equatorial Pacific (EEP) (Fig. 5). As expected, the surface rates of uptake and regeneration are generally lower in the WWP than in the CEP and EEP, which are related to the zonal distributions of surface nutrients and associated biological activities (Wang et al., 2008). However, modeled rates of uptake and regeneration are higher below $80 \mathrm{~m}$ in the WWP than in the EEP. The model produces deep maxima of nitrate uptake, ammonium uptake and regeneration in oligotrophic waters, which have been observed along $150^{\circ} \mathrm{W}$ (Raimbault et al., 1999).

\subsection{Zooplankton excretion and DON/detritus reminer- alization}

Ammonium is primarily generated from zooplankton excretion and DON/detritus remineralization. Based on observations at $150^{\circ} \mathrm{W}$ (Raimbault et al., 1999), DON 

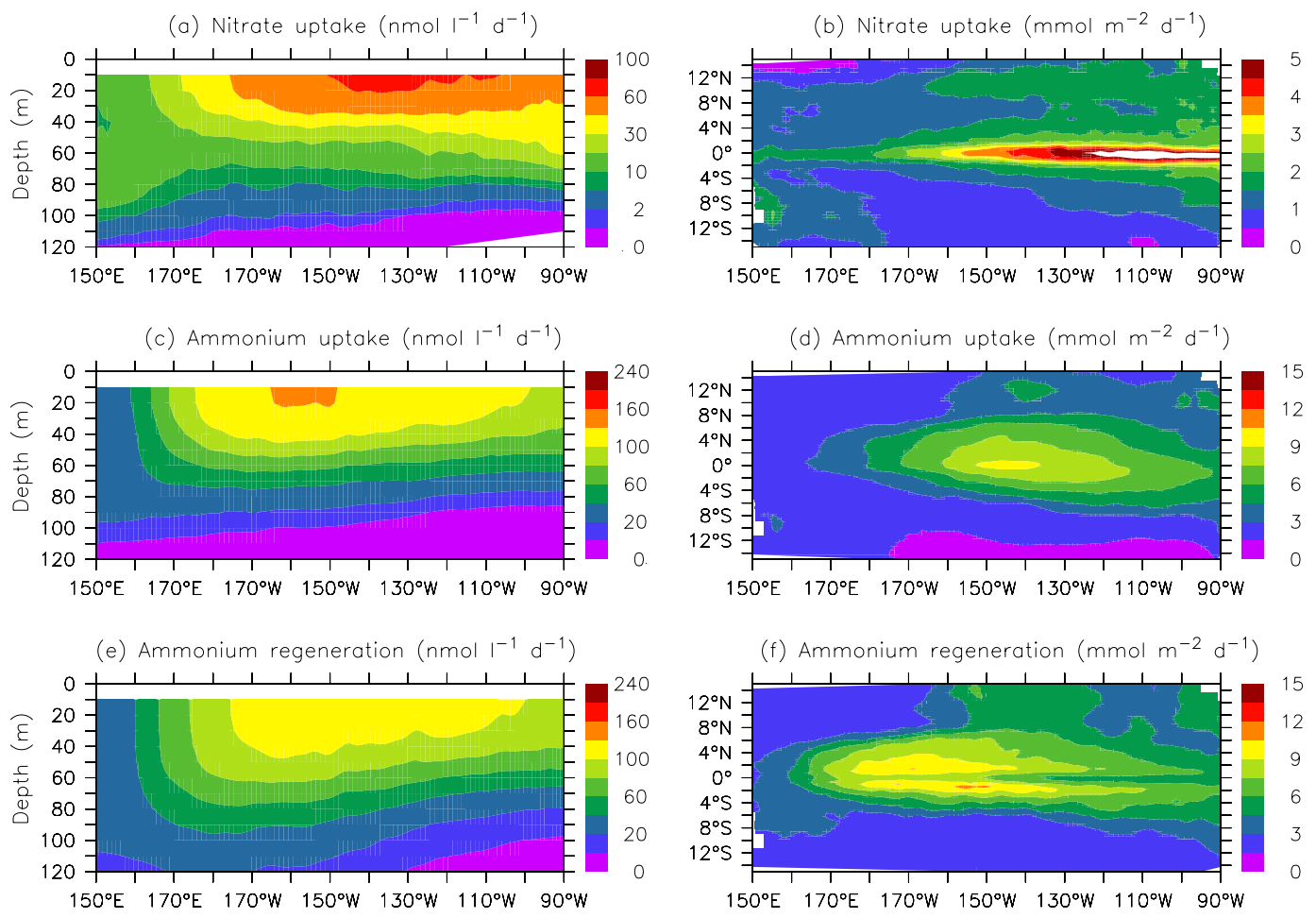

Fig. 4. Averaged rates (1992-1996) of (a) and (b) nitrate uptake, (c) and (d) ammonium uptake, and (e) and (f) ammonium regeneration. Left column: averaged over $5^{\circ} \mathrm{N}-5^{\circ} \mathrm{S}$; right column: integrated over $0-120 \mathrm{~m}$.
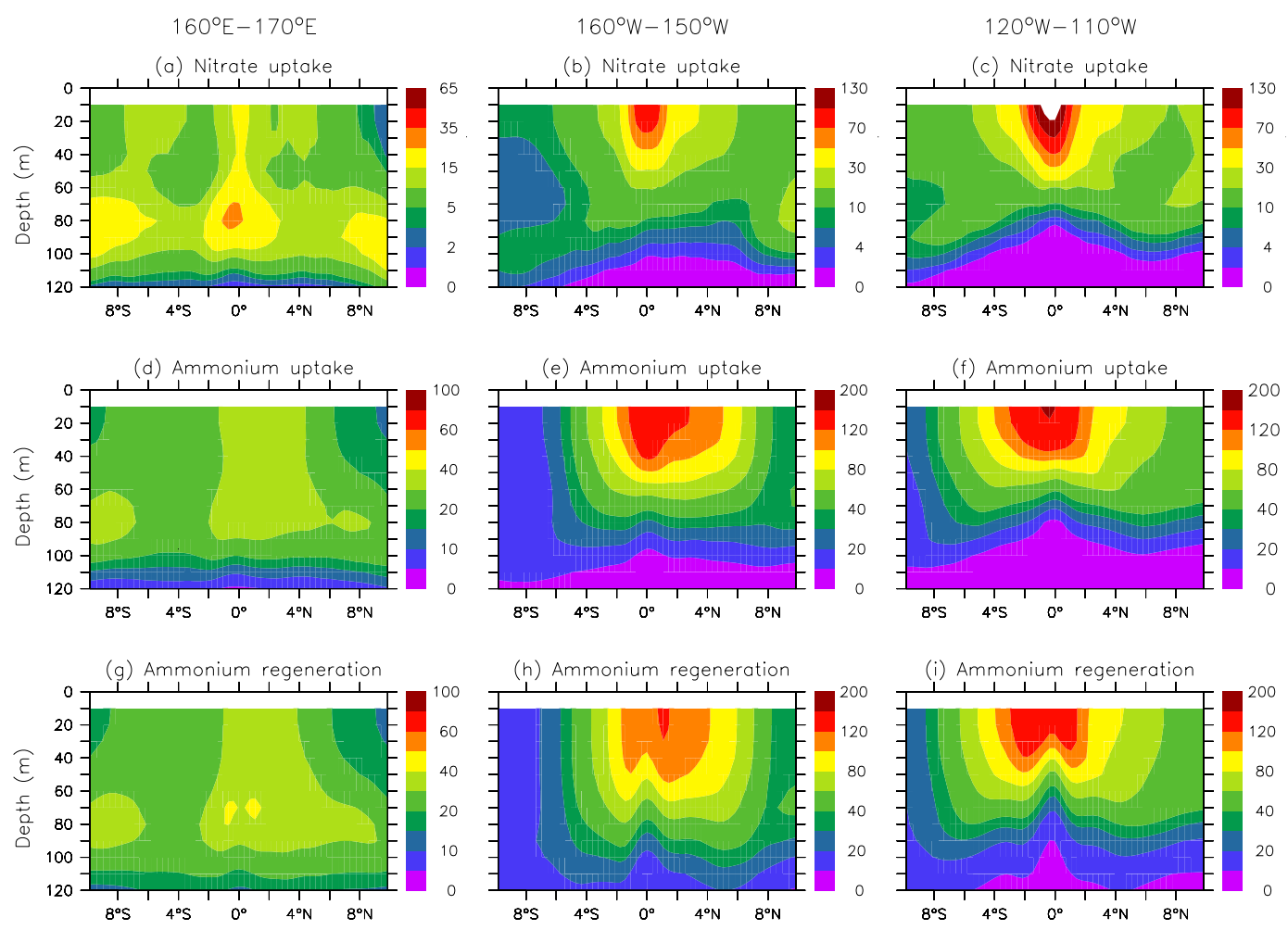

Fig. 5. Averaged rates $\left(\right.$ nmol $1^{-1} \mathrm{~d}^{-1}$ ) of (a), (b) and (c) nitrate uptake, (d), (e) and (f) ammonium uptake, and (g), (h) and (i) ammonium regeneration for the period of 1992-1996, in the western warm pool (left column), the central (middle column) and eastern equatorial Pacific (right column), depth versus latitude. 

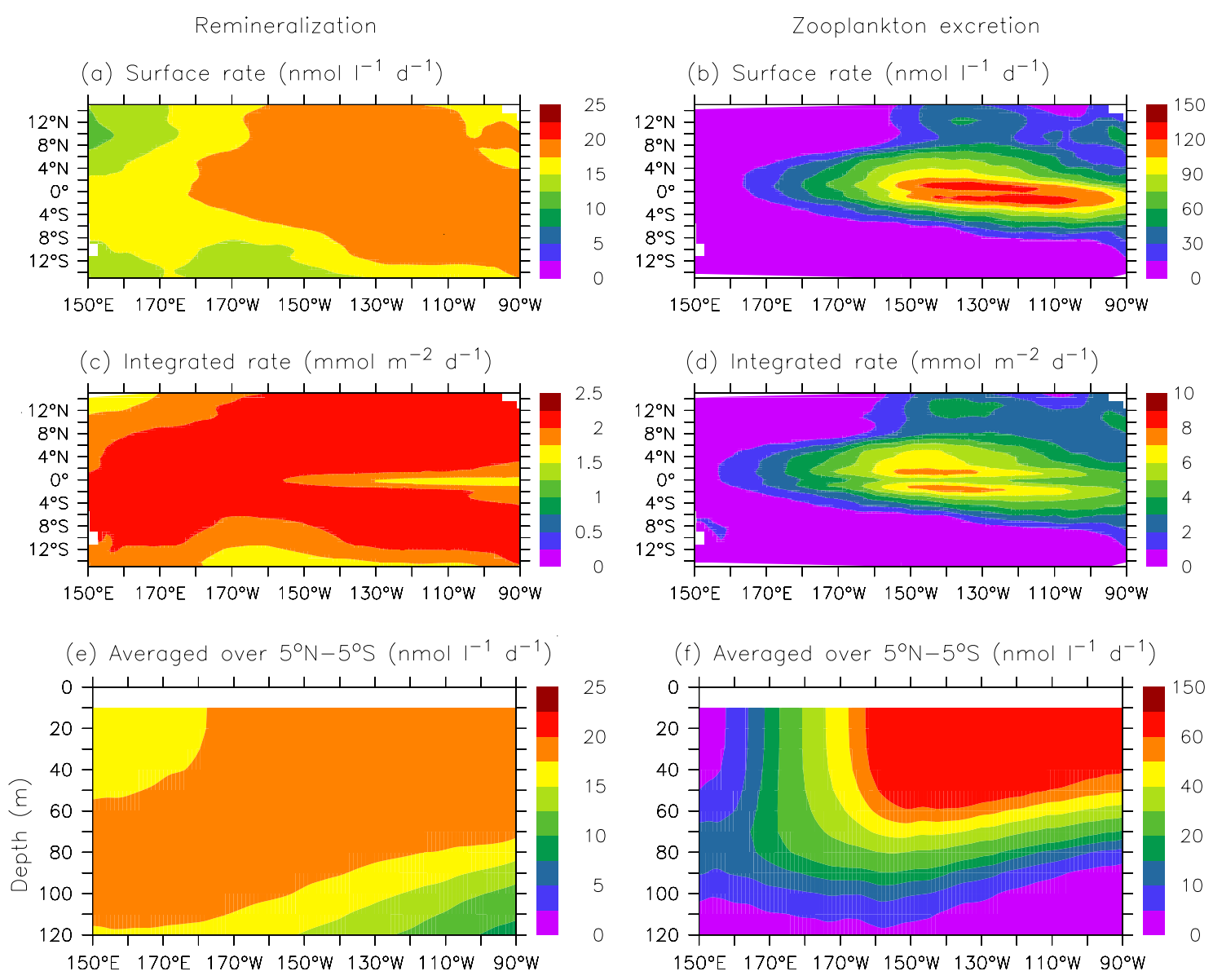

Fig. 6. Averaged rates (1992-1996) of detritus/DON remineralization (left column) and zooplankton excretion (right column) (a) and (b) in surface water, (c) and (d) integrated over $0-120 \mathrm{~m}$, and (e) and (f) averaged over $5^{\circ} \mathrm{N}-5^{\circ} \mathrm{S}$.

shows relatively uniform distribution over 0-200 $\mathrm{m}$ whereas ammonium regeneration occurs mainly in the upper $100 \mathrm{~m}$, suggesting that the major contribution of ammonium regeneration is not from DON remineralization. This modeling study shows that there is little spatial variation in remineralization whereas there is pronounced spatial variability in zooplankton excretion (Fig. 6). For instance, the integrated rate of zooplankton excretion varies from 1 to $\sim 8 \mathrm{mmol} \mathrm{N} \mathrm{m}^{-2} \mathrm{~d}^{-1}$, with the highest off the equator in the central equatorial Pacific. Model simulations show that zooplankton excretion (Fig. 6d and f) solely explains the spatial variability in ammonium regeneration (Fig. $4 \mathrm{e}$ and f).

Figure 7 further shows meridional-vertical comparisons of zooplankton excretion and remineralization among the WWP, the CEP and the EEP. Apparently, there is little meridional or zonal variability with weak vertical variability in remineralization in the upper $150 \mathrm{~m}$ water column. However, there are large zonal, meridional and vertical differences in zooplankton excretion. In general, zooplankton excretion rate is lower in the western oligotrophic waters but higher in the eastern upwelling region. The major role of zooplank- ton in nutrient regeneration has been demonstrated in early studies (Neuer and Franks, 1993; Banse, 1995; Le Borgne, 1986). Particularly, Banse (1995) stated that zooplankton played a pivotal role in controlling the ocean primary production through zooplankton-mediated processes such as sloppy feeding of zooplankton and excretion.

While the model reproduces the magnitudes and meridional distributions of ammonium uptake and regeneration in the upper euphotic zone, the modeled deep maximum of ammonium regeneration is much weaker than the observed one. The defect in simulated ammonium regeneration may partly result from the lack of zooplankton migration in the model. Vertically migrating zooplankton may de-couple the utilization of nutrients in the euphotic zone at night and regeneration of nutrients below the euphotic zone during the daytime (Ashjian et al., 2002; Roman et al., 1995; Roman et al., 2002; Le Borgne et al., 2003), which may be an important mechanisms influencing nutrient cycling in the upper water column. 

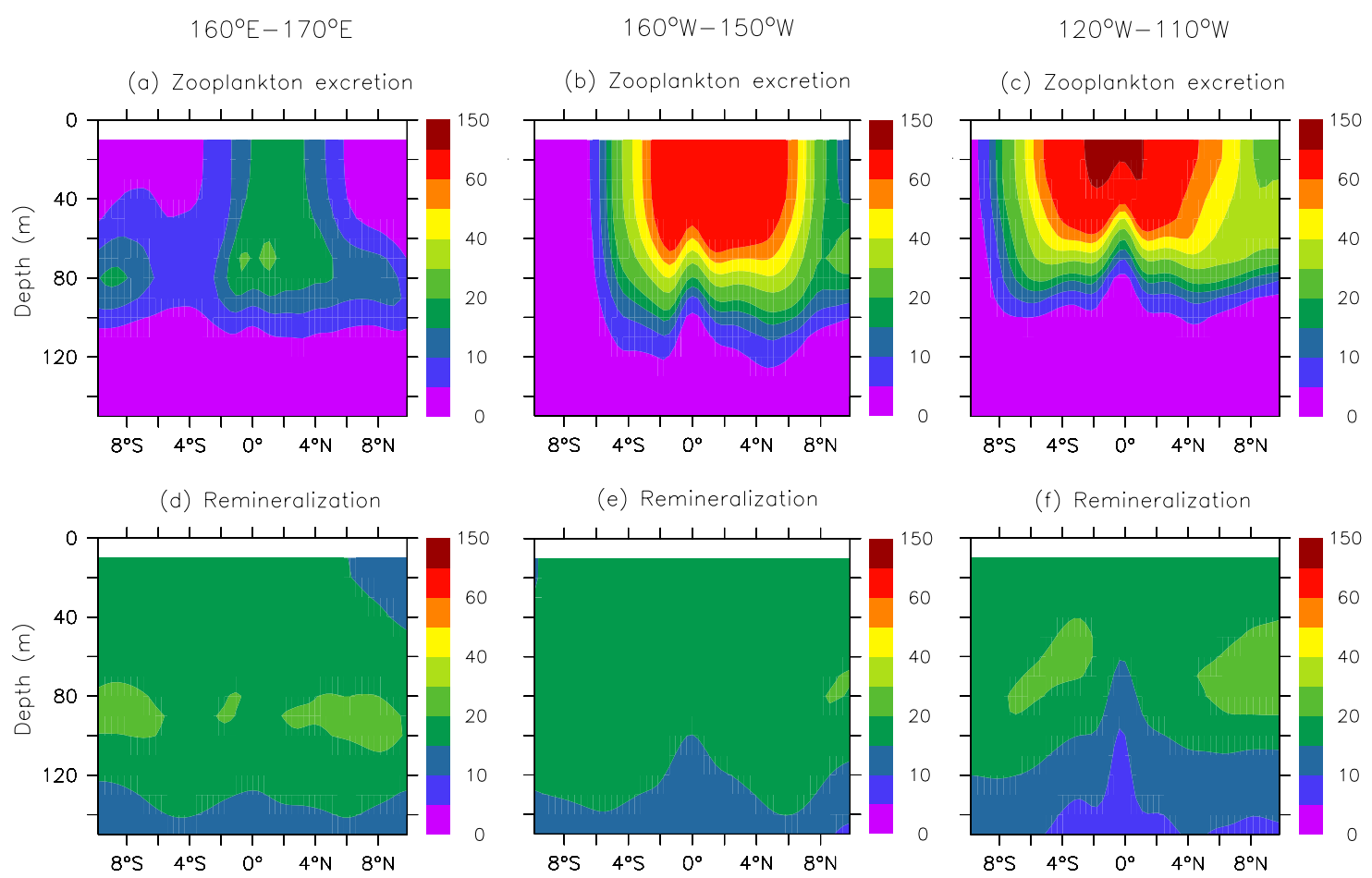

Fig. 7. Averaged rates $\left(n m o l 1^{-1} \mathrm{~d}^{-1}\right)$ of (a), (b) and (c) zooplankton excretion, and (d), (e) and (f) detritus/DON remineralization for the period of 1992-1996, in the western warm pool (left column), the central (middle column) and eastern equatorial Pacific (right column), depth versus latitude.

\subsection{Nitrogen budget}

The fact that ammonium regeneration is greater than ammonium uptake in the lower euphotic zone may explain the observed DAM in the equatorial Pacific (e.g., Eldin and Rodier, 2003; Aufdenkampe et al., 2002; Raimbault et al., 1999). Figure 8 shows the highest ammonium content in the central equatorial Pacific, with higher values off the equator than on the equator. As expected, the subsurface waters contain more ammonium (Fig. 8c) than the surface waters (Fig. 8a). Overall, ammonium distribution shows a significant relationship with that of net ammonium production except in the upper euphotic zone where the net ammonium production is negative in most parts of the basin.

While there are some indications of similarity in the meridional-vertical variations between the net ammonium production and ammonium concentration (Fig. 9), there are considerable mismatches particularly in the eastern upwelling region (Fig. 9c and f). For instance, the DAM is much deeper than the NAP peaks in the CEP and EEP. The negative NAP near the surface suggests non-biogeochemical sources of ammonium into the surface waters, i.e., upwelling of ammonium from the subsurface (NAP peaks) to the surface. The DAM in the subsurface can certainly enhance vertical supply of ammonium through upwelling and vertical mixing.
Table 2 presents analyses of nitrogen budget for some insights of ammonium inputs and removals in the WWP, CEP and EEP. In general, ammonium content and rates of nitrogen fluxes are higher in the CEP and EEP than in the WWP. The exception is that remineralization is slightly higher in the WWP than in the CEP and EEP, which is attributable to the higher temperature in the WWP. The integrated remineralization rate is almost constant $\left(\sim 2 \mathrm{mmol} \mathrm{N} \mathrm{m}^{-2} \mathrm{~d}^{-1}\right)$ across the entire basin whereas zooplankton excretion shows much higher rates in the CEP and $\operatorname{EEP}\left(>5 \mathrm{mmol} \mathrm{N} \mathrm{m}^{-2} \mathrm{~d}^{-1}\right)$ than in the WWP $\left(<1 \mathrm{mmol} \mathrm{N} \mathrm{m}^{-2} \mathrm{~d}^{-1}\right)$. Both ammonium regeneration and uptake reveal similar zonal variability, i.e., much higher rates in the CEP/EEP than in the WWP.

The integrated rate of nitrate uptake is $1.98 \mathrm{mmol} \mathrm{N} \mathrm{m}^{-2} \mathrm{~d}^{-1}$ in the CEP, which is close to the averaged rate of $2 \mathrm{mmol} \mathrm{N} \mathrm{m}^{-2} \mathrm{~d}^{-1}$ measured along $150^{\circ} \mathrm{W}$ in the upwelling region (Raimbault et al., 1999). The integrated rate of nitrate uptake is approximately $40 \%$ higher in the EEP, but $40 \%$ lower in the WWP than in the CEP. Modeled rate of new production ranges from $0.64 \mathrm{mmol} \mathrm{N} \mathrm{m}^{-2} \mathrm{~d}^{-1}$ in the WWP to $1.82 \mathrm{mmol} \mathrm{N} \mathrm{m}^{-2} \mathrm{~d}^{-1}$ in the EEP, which are similar to the observed values (Aufdenkampe et al., 2001; McCarthy et al., 1996). New production is approximately $50 \%$ of nitrate uptake in the WWP and CEP, and 67\% in the EEP. The $f$ ratio $(0.1-0.19)$, the ratio of new production to total nitrogen uptake, is much 

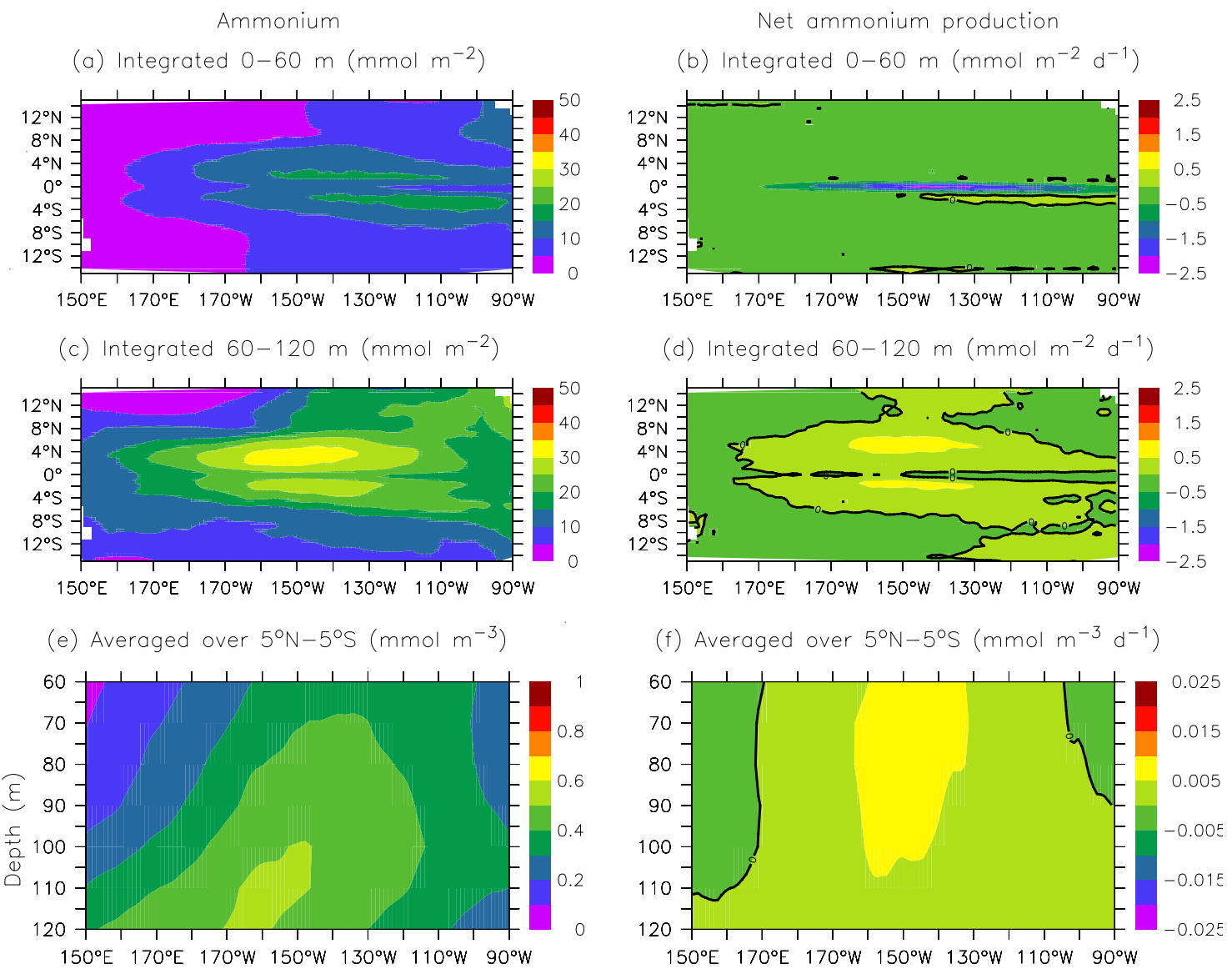

Fig. 8. Modeled means (1992-1996) of ammonium (left column) and net ammonium production (NAP: right column). (a) and (b) integrated over $0-60 \mathrm{~m}$, (c) and (d) integrated over $60-120 \mathrm{~m}$, and (e) and (f) averaged over $5^{\circ} \mathrm{N}-5^{\circ} \mathrm{S}$.

Table 2. Ammonium content $\left(\mathrm{mmol} \mathrm{N} \mathrm{m}{ }^{-2}\right)$, integrated rates $\left(\mathrm{mmol} \mathrm{N} \mathrm{m}^{-2} \mathrm{~d}^{-1}\right)$ over $0-150 \mathrm{~m}$ for zooplankton excretion, remineralization, ammonium regeneration, ammonium uptake, nitrification, nitrate uptake, and total nitrogen uptake, net ammonium production (NAP), and derived $f$ ratios during $1992-1996$ for different boxes in the Pacific $\left(5^{\circ} \mathrm{N}-5^{\circ} \mathrm{S}\right)$.

\begin{tabular}{|c|c|c|c|}
\hline Latitude & $160^{\circ} \mathrm{E}-170^{\circ} \mathrm{E}$ & $160^{\circ} \mathrm{W}-150^{\circ} \mathrm{W}$ & $120^{\circ} \mathrm{W}-110^{\circ} \mathrm{W}$ \\
\hline Ammonium content & 29.70 & 52.26 & 45.58 \\
\hline Zooplankton excretion & 0.76 & 5.60 & 5.45 \\
\hline Remineralization & 2.43 & 2.38 & 1.96 \\
\hline Ammonium regeneration & 3.19 & 7.98 & 7.41 \\
\hline Ammonium uptake & 2.72 & 6.90 & 6.68 \\
\hline Nitrification & 0.59 & 1.05 & 0.91 \\
\hline NAP & -0.12 & 0.03 & -0.18 \\
\hline Nitrate uptake & 1.23 & 1.98 & 2.73 \\
\hline New production ${ }^{\mathrm{a}}$ & 0.64 & 0.93 & 1.82 \\
\hline Total $\mathrm{N}$ uptake & 3.95 & 8.88 & 9.41 \\
\hline$f$ ratio $^{\mathrm{b}}$ & 0.16 & 0.10 & 0.19 \\
\hline$f$ ratio*c & 0.31 & 0.22 & 0.29 \\
\hline
\end{tabular}

\footnotetext{
a New production $=$ nitrate uptake - nitrification

b $f$ ratio $=$ new production/total $\mathrm{N}$ uptake

c $f$ ratio* $=$ nitrate uptake/total $\mathrm{N}$ uptake
} 

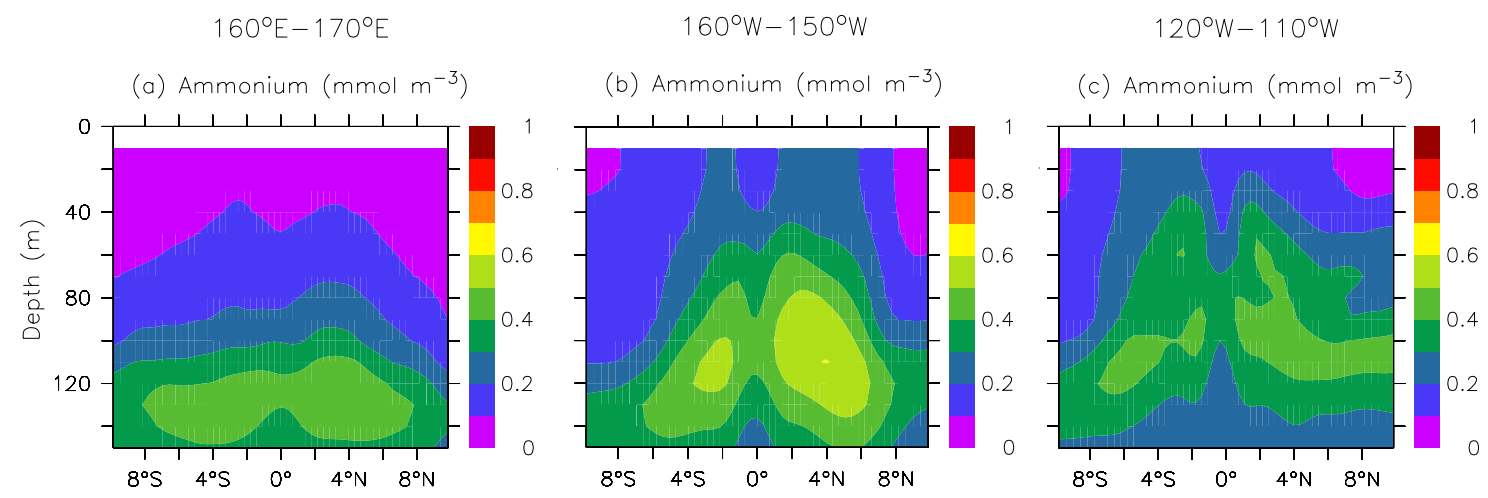

(d) NAP (nmol $\left.\mathrm{I}^{-1} \mathrm{~d}^{-1}\right)$
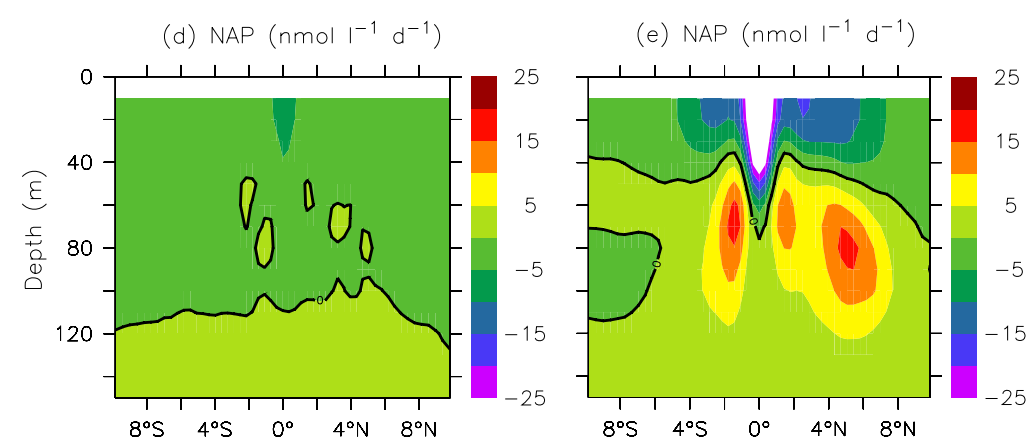

(f) NAP $\left(n m o l l^{-1} d^{-1}\right)$

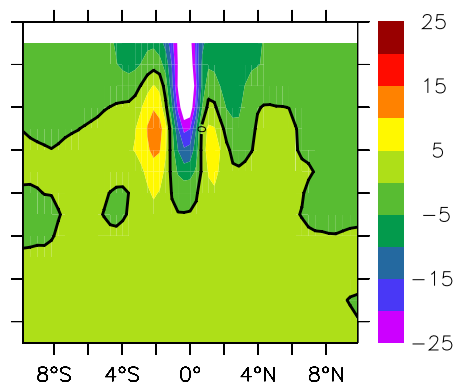

Fig. 9. Averaged concentrations of (a), (b) and (c) ammonium, and rates of (d), (e) and (f) net ammonium production (NAP) for the period of 1992-1996, in the western warm pool (left column), the central (middle column) and eastern equatorial Pacific (right column), depth versus latitude.

smaller than the ratio $(0.22-0.31)$ of nitrate uptake to total nitrogen uptake. Apparently, ignoring nitrification leads to overestimations of new production and $f$ ratio.

The modeled nitrification is approximately $50 \%$ lower in the oligotrophic waters (i.e., WWP) than in the upwelling regions (i.e., CEP and EEP) whereas the measured nitrification varies by a factor of 3 or more from the oligotrophic area to the upwelling area (e.g., Raimbault et al., 1999). Further studies are needed to better understand the regulating processes of nitrification (Wang and Murtugudde, 2009). Interestingly, our study indicates that the parameterization of nitrification has little effect on ammonium regeneration or total nitrogen uptake in the equatorial Pacific. Net ammonium production over the top $150 \mathrm{~m}$ is approximately balanced between the inputs due to zooplankton excretion and DON/detritus remineralization, and removal due to biological uptake and nitrification. The positive NAP $\left(0.03 \mathrm{mmol} \mathrm{m}^{-2} \mathrm{~d}^{-1}\right)$ in the CEP coincides to the highest ammonium content, suggesting that the subsurface surplus of ammonium regeneration is largely responsible for the observed DAM in the equatorial Pacific Ocean.

\section{Conclusions}

We have conducted a basin scale modeling study focusing on nitrogen uptake and regeneration in the equatorial Pacific. Our approach of model assessments includes not only distributions of nitrate and ammonium, but also nitrate uptake, ammonium uptake and regeneration. The model is able to reproduce many observed features in nitrogen fields, including the asymmetries of nitrate and ammonium. In addition, modeled rates of nitrate uptake, ammonium uptake and regeneration generally agree with those of observations. The model also reproduces the observed de-coupling of ammonium uptake and regeneration: uptake greater (smaller) than regeneration in the upper (lower) euphotic zone. The de-coupling, particularly the subsurface surplus of ammonium regeneration, largely explains the observed DAM in the equatorial Pacific Ocean. Overall, net ammonium production over the top $150 \mathrm{~m}$ is approximately balanced between the inputs and removal of ammonium. Our study indicates that zooplankton excretion and DON remineralization play a different role in nitrogen regeneration in the upper ocean. Zooplankton excretion supplies most ammonium in the euphotic zone, and is largely responsible for the spatial variability. DON remineralization provides a steady supply of ammonium in the upper ocean, and is a major source of inorganic nitrogen for the oligotrophic regions. 
Acknowledgements. This work is partly supported by grants from the National Aeronautics and Space Administration. The authors wish to acknowledge use of the Ferret program for analysis and graphics in this paper. Ferret is a product of NOAA's Pacific Marine Environmental Laboratory. (Information is available at http://ferret.pmel.noaa.gov/Ferret/).

Edited by: L. Bopp

\section{References}

Archer, D., Aiken, J., Balch, W., Barber, D., Dunne, J., Flament, P., Gardner, W., Garside, C., Goyet, C., Johnson, E., Kirchman, D., McPhaden, M., Newton, J., Peltzer, E., Welling, L., White, J., and Yoder, J.: A meeting place of great ocean currents: shipboard observations of a convergent front at 2 degrees $\mathrm{N}$ in the Pacific, Deep-Sea Res. Pt. II, 44, 1827-1849, 1997.

Ashjian, C. J., Smith, S. L., Flagg, C. N., and Idrisi, N.: Distribution, annual cycle, and vertical migration of acoustically derived biomass in the Arabian Sea during 1994-1995, Deep-Sea Res. Pt. II, 49, 2377-2402, 2002.

Aufdenkampe, A. K., McCarthy, J. J., Rodier, M., Navarette, C., Dunne, J., and Murray, J. W.: Estimation of new production in the tropical Pacific, Global Biogeochem. Cy., 15, 101-112, 2001.

Aufdenkampe, A. K., McCarthy, J. J., Navarette, C., Rodier, M., Dunne, J., and Murray, J. W.: Biogeochemical controls on new production in the tropical Pacific, Deep-Sea Res. Pt. II, 49, 2619 2648, 2002.

Aufdenkampe, A. K. and Murray, J. W.: Controls on new production: the role of iron and physical processes, Deep-Sea Res. Pt. II, 49, 2649-2668, 2002.

Aumont, O. and Bopp, L.: Globalizing results from ocean in situ iron fertilization studies, Global Biogeochem. Cy., 20, Gb2017, doi:10.1029/2005GB002591, 2006.

Banse, K.: Zooplankton - pivotal role in the control of ocean production, ICES J., Mar. Sci., 52, 265-277, 1995.

Bonnet, S., Biegala, I. C., Dutrieux, P., Slemons, L. O., and Capone, D. G.: Nitrogen fixation in the western equatorial Pacific: Rates, diazotrophic cyanobacterial size class distribution, and biogeochemical significance, Global Biogeochem. Cy., 23, GB3012, doi:10.1029/2008gb003439, 2009.

Bronk, D. A.: Dynamics of DON, in: Biogeochemistry of Marine Dissolved Organic Matter, edited by: Hansell, D. A. and Carlson, C. A., Academic Press, San Diego, USA, 153-247, 2002.

Chavez, F. P. and Barber, R. T.: An estimate of new production in the equatorial Pacific, Deep-Sea Res. Pt. I, 34, 1229-1243, 1987.

Chen, D., Rothstein, L. M., and Busalacchi, A. J.: A hybrid vertical mixing scheme and its application to tropical ocean models, J. Phys. Oceanogr., 24, 2156-2179, 1994.

Christian, J. R., Verschell, M. A., Murtugudde, R., Busalacchi, A. J., and McClain, C. R.: Biogeochemical modelling of the tropical Pacific Ocean I: Seasonal and interannual variability, Deep-Sea Res. Pt .II, 49, 509-543, 2002.

Dadou, I., Lamy, F., Rabouille, C., Ruiz-Pino, D., Andersen, V., Bianchi, M., and Garcon, V.: An integrated biological pump model from the euphotic zone to the sediment: A 1-D application in the Northeast tropical Atlantic, Deep-Sea Res. Pt. II, 48, 2345-2381, 2001.
Denman, K. L.: Modelling planktonic ecosystems: parameterizing complexity, Prog. Oceanogr., 57, 429-452, 2003.

Dugdale, R. C., Wilkerson, F. P., Barber, R. T., and Chavez, F. P.: Estimating new production in the equatorial Pacific-Ocean at 150-Degrees-W, J. Geophys. Res., 97, 681-686, 1992.

Dugdale, R. C., Wischmeyer, A. G., Wilkerson, F. P., Barber, R. T., Chai, F., Jiang, M. S., and Peng, T. H.: Meridional asymmetry of source nutrients to the equatorial Pacific upwelling ecosystem and its potential impact on ocean-atmosphere $\mathrm{CO}_{2}$ flux: a data and modeling approach, Deep-Sea Res. Pt. II, 49, 2513-2531, 2002.

Eldin, G. and Rodier, M.: Ocean physics and nutrient fields along 180 degrees during an El Nino-Southern Oscillation cold phase, J. Geophys. Res., 108, 8137, doi:8110.1029/2000JC000746, 2003.

Feely, R. A., Wanninkhof, R., Goyet, C., Archer, D. E., and Takahashi, T.: Variability of $\mathrm{CO}_{2}$ distributions and sea-air fluxes in the central and eastern equatorial pacific during the 1991-1994 El Niño, Deep-Sea Res. Pt. II, 44, 1851-1867, 1997.

Gent, P. R. and Cane, M. A.: A reduced gravity, primitive equation model of the upper Equatorial Ocean, J. Comput. Phys., 81, 444 480, 1989.

Hopkinson, C. S., Vallino, J. J., and Nolin, A.: Decomposition of dissolved organic matter from the continental margin, Deep-Sea Res. Pt. II, 49, 4461-4478, 2002.

Jiang, M. S., Chai, F., Dugdale, R. C., Wilkerson, F. P., Peng, T. H., and Barber, R. T.: A nitrate and silicate budget in the equatorial Pacific Ocean: a coupled physical-biological model study, DeepSea Res. Pt. II, 50, 2971-2996, 2003.

Jiang, M. S. and Chai, F.: Physical and biological controls on the latitudinal asymmetry of surface nutrients and $p \mathrm{CO}_{2}$ in the central and eastern equatorial Pacific, J. Geophys. Res-Oceans, 110 , C06007, doi:06010.01029/02004JC002715, 2005.

Kalnay, E., Kanamitsu, M., Kistler, R., Collins, W., Deaven, D., Gandin, L., Iredell, M., Saha, S., White, G., Woollen, J., Zhu, Y., Chelliah, M., Ebisuzaki, W., Higgins, W., Janowiak, J., Mo, K. C., Ropelewski, C., Wang, J., Leetmaa, A., Reynolds, R., Jenne, R., and Joseph, D.: The NCEP/NCAR 40-year reanalysis project, B. Am. Meteorol. Soc., 77, 437-471, 1996.

Kug, J. S., Kang, I. S., and An, S. I.: Symmetric and antisymmetric mass exchanges between the equatorial and off-equatorial $\mathrm{Pa}-$ cific associated with ENSO, J. Geophys. Res-Oceans, 108, 3284 doi:3210.1029/2002JC001671, 2003.

Laws, E. A.: New production in the equatorial Pacific: a comparison of field data with estimates derived from empirical and theoretical models, Deep-Sea Res. Pt. I, 51, 205-211, 2004.

Le Borgne, R.: The release of soluble end products of metabolism, in: The biological chemistry of marine copepods, edited by: Corner, E. D. S. and O'Hara, S. C. M., Clarendon Press, Oxford, 107-164, 1986.

Le Borgne, R. and Rodier, M.: Net zooplankton and the biological pump: A comparison between the oligotrophic and mesotrophic equatorial Pacific, Deep-Sea Res. Pt. II, 44, 2003-2023, 1997.

Le Borgne, R., Barber, R. T., Delcroix, T., Inoue, H. Y., Mackey, D. J., and Rodier, M.: Pacific warm pool and divergence: temporal and zonal variations on the equator and their effects on the biological pump, Deep-Sea Res. Pt. II, 49, 2471-2512, 2002.

Le Borgne, R., Champalbert, G., and Gaudy, R.: Mesozooplankton biomass and composition in the equatorial $\mathrm{Pa}-$ 
cific along 180 degrees, J. Geophys. Res., 108, 8143, doi:8110.1029/2001JC000745, 2003.

Le Borgne, R. and Landry, M. R.: EBENE: A JGOFS investigation of plankton variability and trophic interactions in the equatorial Pacific (180 degrees), J. Geophys. Res., 108, 8136, doi:8110.1029/2001JC001252, 2003.

Le Bouteiller, A., Leynaert, A., Landry, M. R., Le Borgne, R., Neveux, J., Rodier, M., Blanchot, J., and Brown, S. L.: Primary production, new production, and growth rate in the equatorial $\mathrm{Pa}-$ cific: Changes from mesotrophic to oligotrophic regime, J. Geophys. Res., 108, 8141, doi:8110.1029/2001JC000914, 2003.

Matsumoto, K., Furuya, K., and Kawano, T.: Association of picophytoplankton distribution with ENSO events in the equatorial Pacific between 145 degrees E and 160 degrees W, Deep-Sea Res. Pt. I, 51, 1851-1871, 2004.

McCarthy, J. J., Garside, C., Nevins, J. L., and Barber, R. T.: New production along $140^{\circ} \mathrm{W}$ in the equatorial Pacific during and following the 1992 El Niño event, Deep-Sea Res. Pt. II, 43, 10651093, 1996.

Mongin, M., Nelson, D. M., Pondaven, P., Brzezinski, M. A., and Treguer, P.: Simulation of upper-ocean biogeochemistry with a flexible-composition phytoplankton model: C, N and Si cycling in the western Sargasso Sea, Deep-Sea Res. Pt. I, 50, 1445-1480, 2003.

Moore, J. K., Doney, S. C., Kleypas, J. A., Glover, D. M., and Fung, I. Y.: An intermediate complexity marine ecosystem model for the global domain, Deep-Sea Res. Pt. II, 49, 403-462, 2002.

Murray, J. W., Johnson, E., and Garside, C.: A U.S. JGOFS process study in the equatorial Pacific (EqPac): Introduction, Deep-Sea Res. Pt. II, 42, 275-293, 1995.

Murtugudde, R., Seager, R., and Busalacchi, A.: Simulation of the tropical oceans with an ocean GCM coupled to an atmospheric mixed-layer model, J. Climate, 9, 1795-1815, 1996.

Neuer, S. and Franks, P. J. S.: Determination of ammonium uptake and regeneration rates using the seawater dilution method, Mar. Biol., 116, 497-505, 1993.

Picaut, J., Ioualalen, M., Delcroix, T., Masia, F., Murtugudde, R., and Vialard, J.: The oceanic zone of convergence on the eastern edge of the Pacific warm pool: A synthesis of results and implications for El Niño-Southern Oscillation and biogeochemical phenomena, J. Geophys. Res., 106, 2363-2386, 2001.

Radenac, M. H., Menkes, C., Vialard, J., Moulin, C., Dandonneau, Y., Delcroix, T., Dupouy, C., Stoens, A., and Deschamps, P. Y.: Modeled and observed impacts of the 1997-1998 El Niño on nitrate and new production in the equatorial Pacific, J. Geophys. Res., 106, 26879-26898, 2001.

Raimbault, P., Slawyk, G., Boudjellal, B., Coatanoan, C., Conan, P., Coste, B., Garcia, N., Moutin, T., and Pujo-Pay, M.: Carbon and nitrogen uptake and export in the equatorial Pacific at 150 degrees W: Evidence of an efficient regenerated production cycle, J. Geophys. Res., 104, 3341-3356, 1999.
Roman, M. R., Dam, H. G., Gauzens, A. L., Urban-Rich, J., Foley, D. G., and Dickey, T. D.: Zooplankton variability on the equator at $140[\mathrm{deg}] \mathrm{W}$ during the JGOFS EqPac study, Deep-Sea Res. Pt. II, 42, 673-693, 1995.

Roman, M. R., Dam, H. G., Le Borgne, R., and Zhang, X.: Latitudinal comparisons of equatorial Pacific zooplankton, Deep-Sea Res. Pt. II, 49, 2695-2711, 2002.

Roussenov, V., Williams, R. G., Mahaffey, C., and Wolff, G. A.: Does the transport of dissolved organic nutrients affect export production in the Atlantic Ocean?, Global Biogeochem. Cy., 20, Gb3002, doi:10.1029/2005GB002510, 2006.

Stoens, A., Menkes, C., Dandonneau, Y., and Memery, L.: New production in the equatorial Pacific: a coupled dynamicalbiogeochemical model, Fish. Oceanogr., 7, 311-316, 1998.

Stoens, A., Menkes, C., Radenac, M. H., Dandonneau, Y., Grima, N., Eldin, G., Memery, L., Navarette, C., Andre, J. M., Moutin, T., and Raimbault, P.: The coupled physical-new production system in the equatorial Pacific during the 1992-1995 El Niño, J. Geophys. Res., 104, 3323-3339, 1999.

Turk, D., Lewis, M. R., Harrison, G. W., Kawano, T., and Asanuma, I.: Geographical distribution of new production in the western/central equatorial Pacific during El Niño and non-El Niño conditions, J. Geophys. Res., 106, 4501-4515, 2001.

Wang, X. J., Murtugudde, R., Busalacchi, A., and Le Borgne, R.: De-coupling of net community production and new production in the equatorial Pacific Ocean: a model study, Geophys. Res. Lett., 32, L21601, doi:10.1029/2005GL024100, 2005.

Wang, X. J., Christian, J. R., Murtugudde, R., and Busalacchi, A. $\mathrm{J}$.: Spatial and temporal variability of the surface water $p \mathrm{CO}_{2}$ and air-sea $\mathrm{CO}_{2}$ flux in the equatorial Pacific during 1980-2003: a basin-scale carbon model, J. Geophys. Res., 111, C07S04, doi:10.1029/2005JC002972, 2006a.

Wang, X. J., Christian, J. R., Murtugudde, R., and Busalacchi, A. J.: Spatial and temporal variability in new production in the equatorial Pacific during 1980-2003: Physical and biogeochemical controls, Deep-Sea Res. Pt. II, 53, 677-697, 2006 b.

Wang, X. J., Le Borgne, R., Murtugudde, R., Busalacchi, A. J., and Behrenfeld, M.: Spatial and temporal variations in dissolved and particulate organic nitrogen in the equatorial Pacific: biological and physical influences, Biogeosciences, 5, 1705-1721, 2008, http://www.biogeosciences.net/5/1705/2008/.

Wankel, S. D., Kendall, C., Pennington, J. T., Chavez, F. P., and Paytan, A.: Nitrification in the euphotic zone as evidenced by nitrate dual isotopic composition: Observations from Monterey Bay, California, Global Biogeochem. Cy., 21, GB2009, doi:2010.1029/2006GB002723, 2007.

Yool, A., Martin, A. P., Fernandez, C., and Clark, D. R.: The significance of nitrification for oceanic new production, Nature, 447, 999-1002, 2007. 